\title{
CIRCULATORY REFLEXES IN TETRAPLEGICS DURING ARTIFICIAL VENTILATION AND GENERAL ANAESTHESIA
}

\author{
By N. C. Welply, C. J. Mathias and H. L. Frankel \\ Department of Anaesthetics and National Spinal Injuries Centre, Stoke Mandeville Hospital, \\ Aylesbury; and Department of Neurology, The Churchill Hospital, Oxford
}

\section{INTRODUCTION}

PATIENTS who are tetraplegic due to cervical spinal cord transections are prone to disorders of the circulation because of the interruption of pathways by which the brain normally controls sympathetic outflow. In these subjects, the haemodynamic response to stimulation of the respiratory tract may differ, as the usual response to such stimulation, hypertension and tachycardia (Corbett et al., 1969), is considered to be dependent on intact autonomic nervous pathways. We therefore studied the cardiovascular system during tracheal suction in recently injured tetraplegics needing I.P.P.V., and during endotracheal intubation in chronic tetraplegics undergoing general anaesthesia. We also report observations on the control of systemic blood pressure in chronic tetraplegics during urological surgery, as visceral stimulation during such surgery can result in severe arterial hypertension (Nieder et al., I970), due to uninhibited reflex sympathetic activity via the isolated spinal cord.

\section{SUBJECTS AND METHODS}

Seven male tetraplegics with physiologically complete cervical spinal cord transections were studied. Four had sustained their lesion recently (within six weeks), and needed respiratory assistance because of paralysis of the diaphragm (Table I). Three were tetraplegic for six months and longer, and needed urological surgery. Five of the patients were studied on more than one occasion.

In all tetraplegics, systolic and diastolic blood pressure, heart rate and the electrocardiograph (E.C.G.) were recorded. In two tetraplegics (Patients no. I and no. 3, Table I), blood pressure was measured by sphygmomanometer and heart rate derived from the E.C.G. In the others, blood pressure and heart rate were measured by intra-arterial catheter. On some occasions, airway pressure was recorded, and blood samples were taken for estimation of plasma electrolytes, arterial blood gases and $\mathrm{pH}$, and plasma noradrenaline and adrenaline.

Intravascular blood pressure was recorded via a polytetrafluoroethylene (Teflon) catheter introduced percutaneously into either the dorsalis pedis or the radial artery. This was connected via saline-filled tubing to an electromanometer, mounted so that throughout the investigation it remained level with the fourth intercostal space, just anterior to the mid-axillary line (phlebostatic axis, Winsor \& Burch, 1946). Between the catheter and the electromanometer was a device (MacMillan \& Stott, I968) which provided continuous perfusion of the catheter 
with sterile heparinised saline and series mechanical damping of the arterial pressure system by an adjustable stenosis. The blood pressure signal triggered a beat-to-beat heart rate meter so that instantaneous heart rate was derived. The E.C.G. was obtained from standard limb and chest leads. These signals were amplified and recorded on a multi-channel rectilinear pen recorder. In some cases, airway pressure was recorded with a pressure transducer connected to the endotracheal tube. Modifications were made to the recorder so that the output from the pre-amplifiers was simultaneously recorded on a four-channel frequencymodulated tape recorder.

The arterial catheter had a three-way connector, which facilitated withdrawal of blood for analysis. Precautions were taken to ensure that the sample was free of saline. Blood for plasma catecholamine analysis was processed as described previously (Mathias et al., 1975). Noradrenaline and adrenaline in plasma were analysed using a double-isotope derivative technique (Christensen, 1973). The lowest value of plasma noradrenaline and adrenaline detectable with this assay is approximately $0.0 \mathrm{I} \mathrm{ng}$. $/ \mathrm{ml}$. with 5 to $\mathrm{IO} \mathrm{ml}$. of plasma. Blood for plasma electrolytes was placed into lithium-heparin tubes and analysed on a Technicon S.M.A. 6-6o. Blood for measurement of blood gases and $\mathrm{pH}$ was withdrawn into heparinised syringes, and analysed on an Instrumentation Laboratory, Model 2 I3 $\mathrm{pH} /$ Blood Gas Analyser.

\section{RESULTS}

In all four recently-injured tetraplegics needing I.P.P.V., tracheal suction in the presence of hypoxia resulted in bradycardia and in two patients even cardiac arrest (Table I and fig. I). Patients no. I and no. 2 had multiple episodes of bradycardia and cardiac arrest during tracheal suction. Atropine successfully prevented this effect. Both these patients needed added oxygen and maintenance atropine $(0.6 \mathrm{mg}$. intramuscularly or subcutaneously every four hours) until their pulmonary function improved. Patient no. 3 developed bradycardia even without tracheal suction. On the seventh day, his heart rate dropped to 40 beats/min. over a period of four hours. Arterial blood gas analysis showed that he was hypoxic, and the addition of oxygen raised his heart rate (fig. 2) and maintained it between 55 and 65 beats/min. Four days later, this patient (no. 3) had a collapsed left lower lobe which made him hypoxic. Tracheal suction at this stage resulted in bradycardia. He was successfully managed on added oxygen and did not need atropine. Patient no. 4 had no pulmonary pathology, was not hypoxic, and did not have bradycardia during tracheal suction. On one occasion, however, his tidal volume fell to $350 \mathrm{ml}$., when the cuff of the endotracheal tube was deflated. This made him hypoxic, and tracheal suction then resulted in bradycardia. This patient was managed on added oxygen. As psychological factors and fear can cause bradycardia and cardiac arrest (Stephenson, 1969), the effect of simulated disconnection from the respirator and tracheal suction ('mock' tracheal suction) was tested in all patients. No change in blood pressure or heart rate was observed.

In the first chronic tetraplegic monitored during general anaesthesia, cardiac arrest occurred during endotracheal intubation (fig. 3). Owing to a delay in the operation list, this patient received atropine $(0.6 \mathrm{mg}$.) and pethilorfan $(50 \mathrm{mg}$.) subcutaneously two hours prior to induction. Methohexitone sodium ( $80 \mathrm{mg}$.) 
TABLE I

Details of recently injured tetraplegics needing intermittent positive pressure ventilation

\begin{tabular}{|l|c|c|c|c|}
\hline & \multicolumn{4}{|c|}{ Patients } \\
\cline { 2 - 5 } & $\mathrm{I}$ & 2 & 3 & 4 \\
\hline & $\mathrm{C} 3 / \mathrm{C}_{4}$ & $\mathrm{C}_{4}$ & $\mathrm{C}_{5}$ & $\mathrm{C}_{4}$ \\
& lesion & lesion & lesion & lesion \\
\hline Tendon reflexes & - & - & - & - \\
Visceral reflexes & - & - & - & - \\
Reflex hypertension to cutaneous and & & & & \\
visceral stimulation & - & - & - & - \\
Resting plasma catecholamines & $\mathrm{NT}$ & $\downarrow$ & $\mathrm{NT}$ & $\downarrow$ \\
Rise in plasma noradrenaline following & & & & - \\
cutaneous and visceral stimulation & $\mathrm{NT}$ & - & $\mathrm{NT}$ & - \\
Plasma electrolytes & $\mathrm{N}$ & $\mathrm{N}$ & $\mathrm{N}$ & $\mathrm{N}$ \\
Pulmonary pathology & + & + & + & - \\
$\mathrm{P}_{\mathrm{a}} \mathrm{O}_{2}$ & $\downarrow$ & $\downarrow$ & $\downarrow$ & $\mathrm{N}(\downarrow)$ \\
Tracheal suction & $\mathrm{CA}$ & $\mathrm{CA}$ & $\mathrm{B}$ & $-(\mathrm{B})$ \\
'Mock' tracheal suction & - & - & - & - \\
\hline
\end{tabular}

NT $=$ Not Tested, $\mathbf{N}=$ Normal, $\downarrow=$ Low, CA $=$ Cardiac Arrest, $\mathrm{B}=$ Bradycardia. $-=$ Absent or no change, $+=$ Present

and suxamethonium chloride (50 mg.) were administered intravenously before intubation. Cardiac arrest followed, which necessitated external cardiac massage. Succeeding tetraplegics undergoing surgery under general anaesthesia were given atropine $(0.6 \mathrm{mg}$.) intravenously a few minutes before induction and intubation. This caused a rise in heart rate and a small elevation in arterial blood pressure, and no further episodes of bradycardia or cardiac arrest occurred. The same patient (as in fig. 3) needed further urological surgery. He was given atropine $0.6 \mathrm{mg}$. intravenously too, and had no fall in heart rate during intubation.

The arterial blood pressure, heart rate and E.C.G. were recorded in chronic tetraplegics before, during and after urological surgery under general anaesthesia. Before surgery, the cardiovascular responses to cutaneous and bladder stimulation were assessed in all patients, while the Valsalva manoeuvre was only tested in those patients who could actively increase intrathoracic pressure. In all patients cutaneous stimulation, by noxious stimuli below the segmental level of the lesion, resulted in a rise in systolic and diastolic blood pressure and a fall in heart rate (Table II). Bladder stimulation, effected by suprapubic percussion of the anterior abdominal wall for periods of one to three minutes, consistently caused marked hypertension the systolic blood pressure often rising above $200 \mathrm{~mm}$. Hg. This was accompanied by a fall in heart rate. In the tetraplegics, the Valsalva manoeuvre (during which the patient acutely increased intrathoracic pressure by taking a deep inspiration, and then attempted to expire forcibly while closing his nose (against a mercury 
I.P.P.V.-6hrs. post ATROPINE (0.6 mgm I.V.)

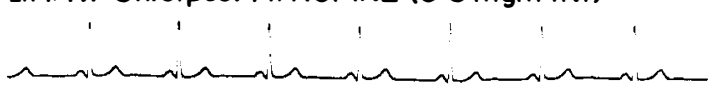

No I.P.P.V.

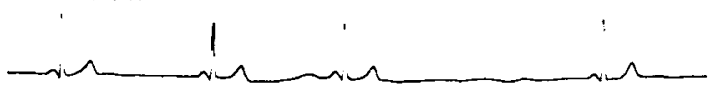

I.P.P.V.
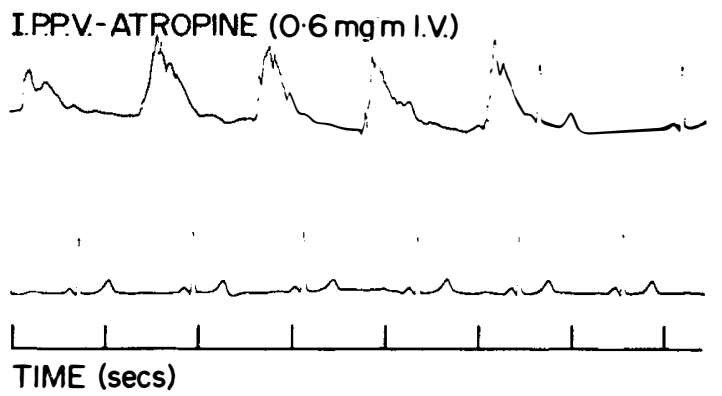

FIG. I

The electro cardiograph in a recently-injured tetraplegic on intermittent positive pressure ventilation (I.P.P.V.). When the patient was taken off the respirator for routine tracheal suction, cardiac arrest occurred. The patient was put back on I.P.P.V. and external cardiac massage and atropine ( $0.6 \mathrm{mg}$. intravenously) was needed.

(2)

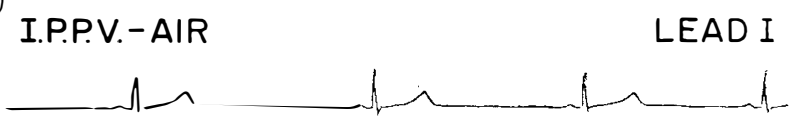

I.P.P.V.-ADDED $\mathrm{O}_{2}$

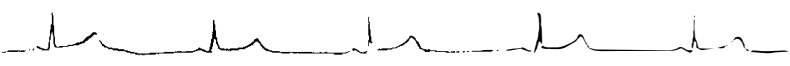

TIME (secs)

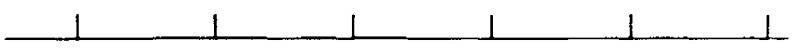

FIG. 2

The electrocardiograph in a recently injured tetraplegic on intermittent positive pressure ventilation (I.P.P.V.) before and after the administration of oxygen. $\mathrm{P}_{\mathrm{a}} \mathrm{O}_{2}$ was low when he was on air; this was corrected after adding oxygen. I3/3-D 


\section{TABLE II}

Cardiovascular variables in a chronic tetraplegic before, during and after urological surgery (transurethral resection and external sphincterotomy) under general anaesthesia

\begin{tabular}{|c|c|c|c|c|}
\hline & \multicolumn{3}{|c|}{ Blood pressure (mm. $\mathrm{Hg}$ ) } & \multirow{2}{*}{$\begin{array}{l}\text { Heart rate } \\
\text { (beats/min.) }\end{array}$} \\
\hline & Systolic & Diastolic & Mean & \\
\hline \multicolumn{5}{|l|}{ Before operation } \\
\hline Resting & I40 & 64 & 89 & 60 \\
\hline Cutaneous stimulation & 168 & 80 & 109 & 48 \\
\hline Bladder stimulation-peak & 220 & I08 & 145 & 52 \\
\hline Bladder stimulation-I min. & 196 & 85 & 122 & 42 \\
\hline \multicolumn{5}{|l|}{ During operation } \\
\hline Resting $-2 \%$ halothane & 120 & 70 & 87 & 95 \\
\hline Resting $-3 \%$ halothane & 85 & 50 & 62 & 90 \\
\hline \multicolumn{5}{|l|}{ Bladder surgery and diathermy } \\
\hline (D) $-3 \%$ halothane & 170 & 80 & IIO & II 2 \\
\hline I.P.P.V. and D. $-\mathrm{I} \%$ halothane & IIO & 58 & 75 & II 5 \\
\hline I.P.P.V.-I $\%$ halothane & 90 & 52 & 68 & IIO \\
\hline After operation & & & & \\
\hline After 2 min. of spontaneous & & & & \\
\hline $\begin{array}{l}\text { respiration (12 min. after } \\
\text { stopping halothane) }\end{array}$ & I 28 & 72 & 9I & 125 \\
\hline $20 \mathrm{~min}$. later & I 28 & 70 & 89 & 78 \\
\hline
\end{tabular}

column) resulted in an abnormal response. The increase in intrathoracic pressure caused a continuous fall of systolic, diastolic and pulse pressure (fig. 4), with no tendency to level off, as occurs in the normal response (fig. 5). In the tetraplegics, the heart rate rose when intrathoracic pressure was elevated. When intrathoracic pressure was released there was no blood pressure overshoot and bradycardia, but only a gradual recovery of blood pressure and heart rate to former levels.

During surgery, halothane (in concentrations of one to three per cent) reduced resting arterial blood pressure, and suppressed the severe hypertension which can occur during bladder surgery. This reduction in blood pressure appeared to be dose-dependent. Halothane concentrations over three per cent were never administered. On some occasions, however, the blood pressure was not adequately controlled with three per cent halothane. The patient was then placed on I.P.P.V. (using a Manley respirator) and the halothane concentration could then be reduced to 0.5-I per cent. This combination effectively controlled systemic blood pressure (Table II and fig. 6). Haemodynamic measurements were continued for one to three hours after the operation. The blood pressure and heart rate soon settled to within normal values (Table II) and no eventful changes occurred. 

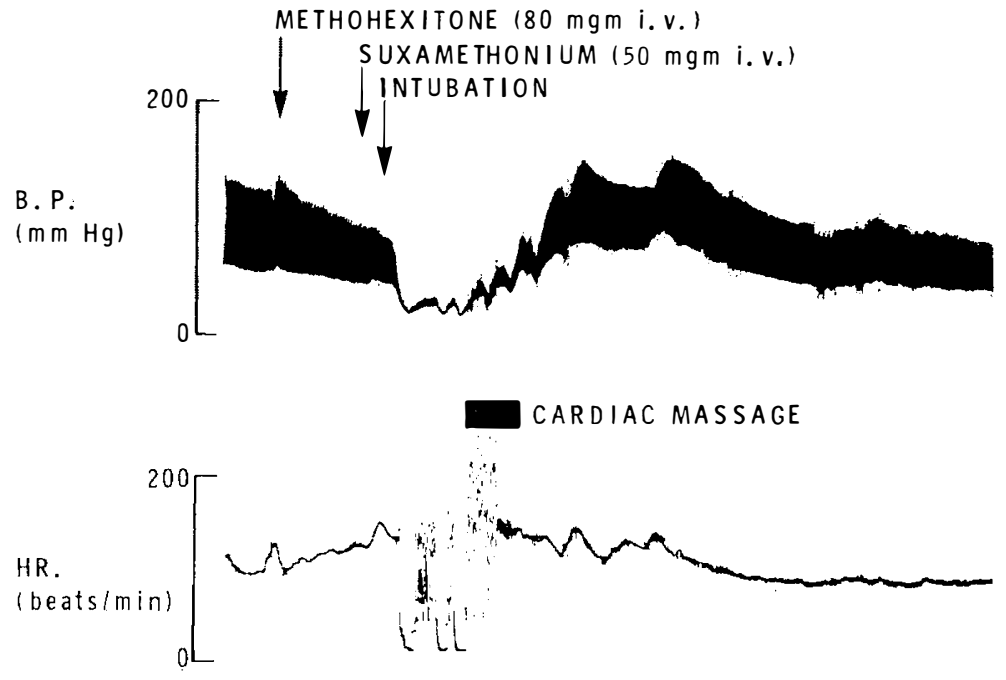

TIME (min)

FIG. 3

Effect of endotracheal intubation on the blood pressure (B.P.) and heart rate (H.R.) of a tetraplegic. The patient was manually inflated with oxygen immediately after cardiac arrest occurred.

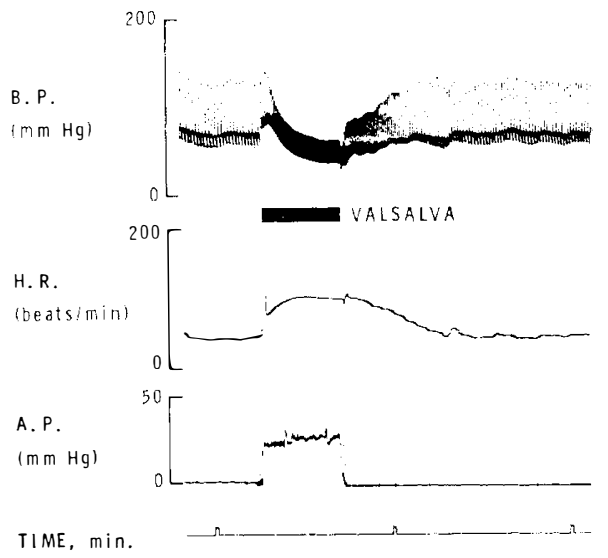

FIG. 4

Effect of a Valsalva manoeuvre on the blood pressure (B.P.) and heart rate (H.R.) of a tetraplegic with a complete C6 lesion (patient no. 6). Airway pressure (A.P.) has been recorded. 


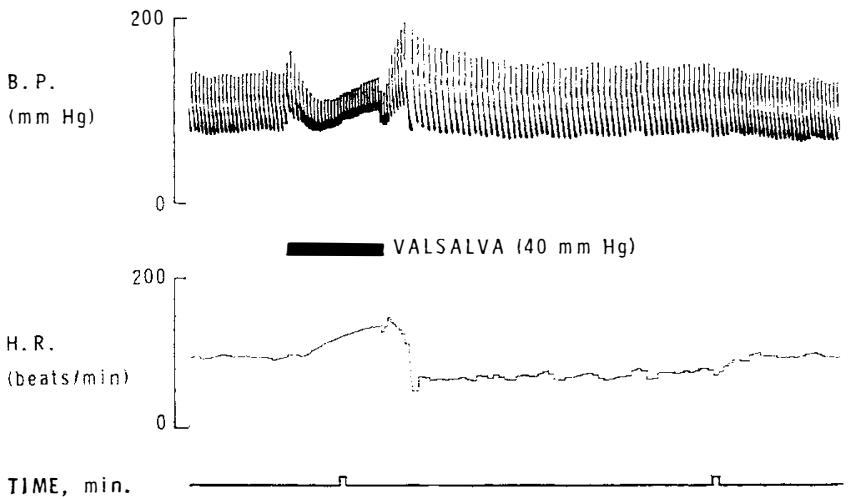

FIG. 5

Effect of a Valsalva manoeuvre on the blood pressure (B.P.) and heart rate (H.R.) of a paraplegic with a complete $\mathrm{L}_{3}$ lesion (and an intact sympathetic nervous system).

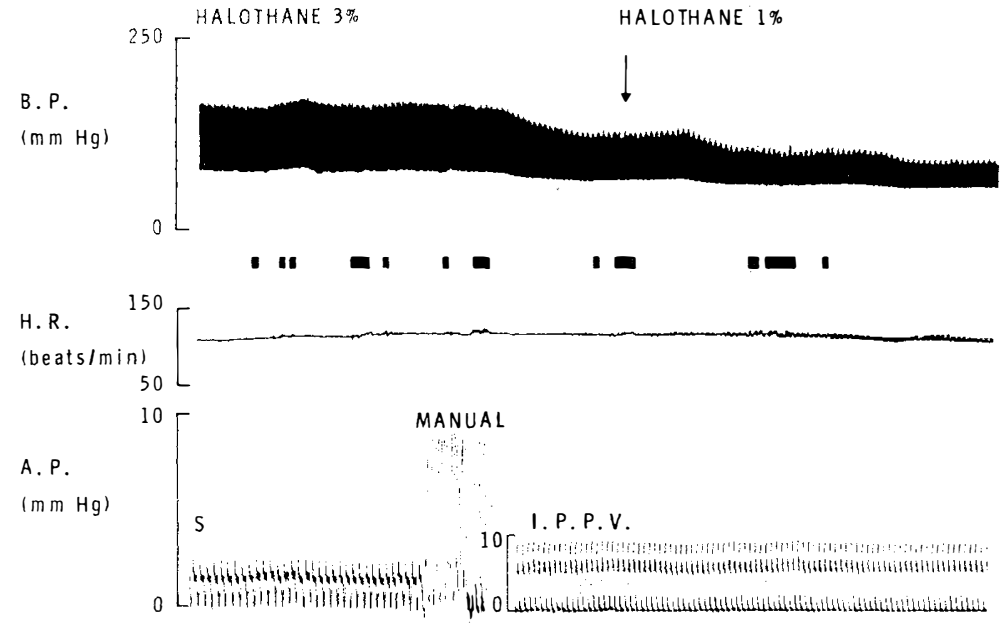

TIME, min.

Fig. 6

Effect of halothane and intermittent positive pressure ventilation (I.P.P.V.) on the blood pressure (B.P.) and heart rate (H.R.) of a tetraplegic (patient no. 6) during urological surgery. The blocks below the B.P. trace indicate bladder stimulation by diathermy. Airway pressure (A.P.) has been recorded during spontaneous breathing (S), manual ventilation and I.P.P.V. 


\section{DISCUSSION}

Tracheal suction and intubation in man usually results in tachycardia and hypertension (Burstein et al.: I950; King et al., I95 I; Rosner et al., I953; Takeshima et al., 1964; Corbett et al., 1969; Forbes \& Dally, 1970). Similar changes occur in animals during mechanical irritation of the respiratory tract (Tomori \& Widdicombe, 1969), and are associated with increased efferent sympathetic nervous activity. It is thought that an intact sympathetic nervous system is necessary for these responses to occur in man. None of our four recently injured tetraplegics on I.P.P.V. had a rise in blood pressure or heart rate during tracheal suction. This was probably due to absent reflex sympathetic activity as all our tetraplegics were in spinal shock.

Tracheal suction resulted in bradycardia and even cardiac arrest. This was probably due to a vago-vagal reflex, with both afferent and efferent arcs in the vagus nerve (Weiss \& Ferris, I934). Vagal sensory receptors are present in the trachea and bronchi and mechanical irritation of these may result in a reflex bradycardia (Stephenson, 1969). The efferent limb was probably the vagus, as atropine effectively abolished the reflex.

Reflex bradycardia and cardiac arrest only occured when the patients were hypoxic as a result of pulmonary pathology or hypoventilation (Table I). In animals, hypoxic stimulation of arterial chemoreceptors, when pulmonary ventilation is constant, results in a reflex bradycardia (Daly \& Scott, I958; Angell-James \& Daly, 1969). In spontaneously breathing animals, this primary bradycardia is converted into a secondary tachycradia by the hypoxic drive which results in hyperventilation and activation of the pulmonary (inflation) vagal reflex (AngellJames \& Daly, 1969; Daly, 1972). None of our tetraplegic patients was, however, capable of spontaneous respiration at the time when bradycardia and cardiac arrest occurred.

Our studies, therefore, indicate that tracheal suction in recently-injured tetraplegics may result in reflex bradycardia and cardiac arrest, especially in the presence of hypoxia. In our patients this appeared to be due to a vago-vagal reflex, which would normally be overridden by sympathetic activity and the pulmonary (inflation) vagal reflex arising from the hypoxic drive to increase ventilation. Atropine effectively abolished this reflex. The management of such patients in emergency is by external cardiac massage and intravenous atropine. Prevention of hypoxia is important. If adequate oxygenation cannot be achieved, maintenance atropine may be necessary. Parasympatheticomimetic drugs should be avoided in these patients.

Reflex cardiac arrest may also occur in tetraplegics during endotracheal intubation. In our patient this was probably due to a vago-vagal reflex. Atropine, $0.6 \mathrm{mg}$. intravenously prior to induction and intubation, effectively prevented this occurrence in succeeding patients. It is suggested that premedication with atropine is essential in tetraplegics undergoing endotracheal intubation and general anaesthesia.

Severe arterial hypertension can occur in tetraplegics undergoing urological surgery (Nieder et al., 1970, Welply, 1975), as visceral stimulation results in uninhibited reflex sympathetic activity via the isolated spinal cord (Guttman \& Whitteridge, I947; Corbett et al., I97I; Debarge et al., I974; Frankel et al., I974). In our patients, halothane reduced the resting blood pressure and the arterial 
pressor response to bladder stimulation during such surgery. It was originally thought that the hypotensive effects of halothane were caused by ganglionic blockade (Raventos, 1956), and in part by a dilating action on vascular smooth muscle (Burn \& Epstein, 1959). It is now thought that the hypotensive effect is due to impairment of myocardial contractility (Prys-Roberts et al., 1974). This may be of importance if an emergency occurs, as the response of the heart to either direct or sympathomimetic stimulation is severely impaired when a low arterial pressure is associated with myocardial depression (Gersh et al., 1972).

In our patients, control of blood pressure during urological surgery was satisfactorily achieved, with low concentrations of halothane (0.5-I per cent), by placing them on I.P.P.V. The facilitatory effect of I.P.P.V. on halothane-induced hypotension has been previously ascribed to the avoidance of hypercapnia and the increase in intrathoracic pressure (Bahlman et al., 1972). It is likely that the increase in intrathoracic pressure is of greater importance in our subjects. The ability of the cardiovascular system to counteract the effects of an increase in intrathoracic pressure depends on the integrity of compensating nervous reflexes. Our tetraplegic patients had abnormal circulatory responses to the Valsalva manoeuvre ('blocked' Valsalva response) (fig. 4), which has been attributed to the interruption of circulatory reflexes by the spinal cord lesion (Johnson et al., I969). The increase in intrathoracic pressure continuously decreased systemic arterial pressure, while restoration of intrathoracic pressure to normal produced only a slow recovery of arterial pressure, with no overshoot as occurs normally (fig. 5). I.P.P.V. is considered to be a series of short repeated Valsalva manoeuvres, and the increase in intrathoracic pressure, in the presence of small concentrations of halothane, probably resulted in a greater reduction of arterial pressure in our tetraplegics, than would occur in subjects with an intact sympathetic nervous system.

Our studies suggest that halothane is effective in controlling the arterial hypertension associated with autonomic hyperreflexia during urological surgery. Control of blood pressure, with low concentrations of halothane, may also be achieved by using I.P.P.V.

\section{SUMMARY}

The arterial blood pressure, heart rate and electrocardiograph were recorded, and plasma electrolytes, arterial blood gases and $\mathrm{pH}$, and plasma catecholamines were estimated in seven patients with physiologically complete cervical spinal cord transections who needed intermittent positive pressure ventilation (I.P.P.V.) or were undergoing urological surgery under general anaesthesia.

In the tetraplegics on I.P.P.V., bradycardia, and in two patients even cardiac arrest, occurred during tracheal suction, especially in the presence of hypoxia. In one tetraplegic being anaesthetised, cardiac arrest occurred during endotracheal intubation. This reflex bradycardia and cardiac arrest appeared to be due to a vago-vagal reflex, unopposed by sympathetic activity or by the pulmonary (inflation) vagal reflex. Atropine was effective in preventing this reflex.

In the tetraplegics undergoing urological surgery, severe hypertension resulting from visceral stimulation was effectively reduced by halothane. In these patients, control of arterial blood pressure with lower concentrations of halothane may also be achieved with I.P.P.V. 


\section{ZUSAMMENFASSUNG}

Der arterielle Blutdruck, Herzfrequenz und Elektrokardiogram wurden aufgezeichnet, und die Plasma Elektrolyte, arterielle Blutgase, ph und Plasma-Katecholamine wurden bestimmt bei sieben Patienten mit physiologisch kompletter cervicaler Rückenmarksdurchstrennung, die intermittierende positive Druckbeatmung (I.P.P.V.) benötigten, oder an denen urologisch chirurgische Eingriffe unter Allgemeinnarkose vorgenommen wurden.

Bei Tetraplegikern mit intermittierend positiver Druckbeatmung (I.P.P.V.) trat Bradykardie auf, und bei zwei Patienten sogar Herzstillstand während trachealer Absaugung, insbesondere bei Hypoxie. Bei einem narkotisierten Tetraplegiker trat während Intubation Herzstillstand auf. Diese Bradykardie und der Herzstillstand schienen einem Vagusreflex zuzuschreiben zu sein, ungehemmt von sympathischer Aktivität oder vom pulmonalen (Inflation reflex) vagalen Reflex. Atrophie verhütete diesen Reflex.

Bei Tetraplegikern, die sich urologischen Eingriffen unterzogen, wurde der schwere Hypertonus, verursacht durch die viszerale Stimulation, wirksam herabgesetzt durch Halothan. Bei diesen Patienten kann die Kontrolle des arteriellen Blutdruckes während solcher Eingriffe auch mit intermittierend positiver Druckbeatmung (I.P.P.V.) erreicht werden.

\section{SOMMAIRE}

La tension artérielle, le débit sanguin et l'électrocardiographe furent enregistrés, et les électrolytes du plasma, les gaz sanguins et le $\mathrm{pH}$, et les catécholamines du plasma furent estimés chez sept malades avec lésion transverse, complète du point de vue physiologique, de la moelle cervicale, qui avaient besoin de la ventilation à pression positive intermittente ou qui subissaient une intervention chirurgicale urologique sous anesthésie générale.

Chez les tétraplèges à qui l'on administrait la ventilation à pression positive intermittente, une bradycardie, et chez deux malades un arrêt du coeur, se produisirent lors d'une succion trachéale, surtout en présence d'une hypoxémie. Chez un tétraplège sous anesthésie un arrêt du coeur se produisit au cours d'une intubation. Cette bradycardie et cet arrêt du coeur réflexes semblent être dus à un réflexe vago-vagal, auquel aucune activité sympathique ni aucun réflexe vagal pulmonaire ne s'opposaient. L'atropine prévint ce réflexe efficacement.

Chez les tétraplèges qui subissaient une intervention chirurgicale urologique, l'halothane réduisait efficacement l'hypertension aiguë qui s'ensuivait de la stimulation viscérale. Chez ces malades l'on peut aussi régler la tension artérielle lors d'une telle intervention chirurgicale avec la ventilation à pression positive intermittente.

Acknowledgements. We thank Dr. J. J. Walsh and Dr. J. M. K. Spalding for equipment, facilities and advice, Dr. N. J. Christensen for the plasma catecholamine analysis, and Mr. R. G. Burr for the blood gas analysis. We are grateful to Mr. I. Nuseibeh for his cooperation during the urological operations, and thank Mrs. P. Smith for excellent technical help. The nursing and medical staff of the National Spinal Injuries Centre have provided much assistance. These studies were performed when C. J. M. was a Rhodes Scholar at the University of Oxford.

\section{REFERENCES}

ANGell-James, JenNifer \& DALY, M. DE BURGH (1969). Cardiovascular responses in apnoeic asphyxia: role of arterial chemoreceptors and the modification of their effects by a pulmonary vagal inflation reflex. F. Physiol. (Lond.), 201, 87-104.

Bahlman, S. H., Eger, E. I., Jr., Halsey, M. J., Stevens, W. C., Shakespeare, T. F., Smith, N. T., Cromwell, T. H. \& FourCade, H. (1972). The cardiovascular effects of halothane in man during spontaneous ventilation. Anesthesiol. 36, 494-502.

Burn, J. H. \& Epstein, H. G. (I959). Hypotension due to halothane. Brit. F. Anaesth. 3I, I99-204. 
Burnstein, C. L., Lo Pinto, F. J. \& Newman, W. (I950). Electrocardiographic studies during endotracheal intubation, I: Effects during usual routine techniques. Anesthesiol. I I, 224-237.

Christensen, N. J. (I973). Plasma noradrenaline and adrenaline in patients with thyrotoxicosis and myxoedema. Clin. Sci. and Mol. Med. 45, I63-I7I.

Corbett, J. L., Frankel, H. L. \& HARris, P. J. (I97I). Cardiovascular reflex responses to cutaneous and visceral stimuli in spinal man. $\mathcal{F}$. Physiol. (Lond.), 21 5, 395-409.

Corbett, J. L., Kerr, J. H. \& Prys-Roberts, C. (I969). Cardiovascular responses to aspiration of secretions from the respiratory tract in man. F. Physiol. (Lond,) 2or, 4IP-43P.

DALY, M. DE BURGH (1972). Interaction of cardiovascular reflexes. In Scientific Basis of Medicine, Eds. Gilliland, I. and Francis, J., pp. 307-332. Athlone Press.

DALY, M. DE BURGH \& SCOTT, MARY J. (I958). The effects of stimulation of the carotid body chemoreceptors on heart rate in the dog. F. Physiol. (Lond.), I 44, I48-I66.

Debarge, O., Christensen, N. J., Corbett, J. L., Eidelman, B. H., Frankel, H. L. \& Mathias, C. J. (1974). Plasma catecholamines in tetraplegics. Paraplegia, I2, 44-49.

Forbes, A. M. \& Dally, F. G. (1970). Acute hypertension during induction of anaesthesia and endotracheal intubation in normotensive man. Brit. F. Anaesth. 42, 618-624.

Frankel, H. L., Mathias, C. J. \& Walsh, J. J. (I974). Blood pressure, plasma catecholamines and prostaglandins during artificial erection in a male tetraplegic. Paraplegia, I2, 205-2 I I.

Gersh, B. J., Prys-Roberts, C. \& Baker, A. B. (I972). The effects of halothane on the interactions between myocardial contractility, aortic impedance, and left ventricular performance, II: Aortic input impedance and the distribution of energy during ventricular ejection. Brit. F. Anaesth. 44, 767-1005.

GuttmanN, L. \& WhitTERIDGe, D. (I947). Effects of bladder distension on autonomic mechanisms after spinal cord injuries. Brain, 70, 36I-404.

Johnson, R. H., Smith, A. C. \& Spalding, J. M. K. (I969). Blood pressure response to standing and to Valsalva's manoeuvre: independence of the two mechanisms in neurological diseases including cervical cord lesions. Clin. Sci. 36, 77-86.

King, B. D., Harris, L. C., Jr., Greifenstein, F. E., Elder, J. D. \& Dripps, R. D. (I95I). Reflex circulatory responses to direct laryngoscopy and tracheal intubation performed during general anaesthesia. Anesthesiol. 12, 556-566.

MacMillan, A. L. \& StotT, F. D. (1968). Continuous intra-arterial blood pressure measurement. Bio-med. Engineering, 3, 20-27.

Mathias, C. J., Christensen, N. J., Corbett, J. L., Frankel, H. L., Goodwin, T. J. \& PEART, W. S. (1975). Plasma catecholamines, plasma renin activity and plasma aldosterone in tetraplegic man, horizontal and tilted. Clin. Sci. and Mol. Med. (in press).

Nieder, R. M., O’Higgins, J. W. \& Aldrete, J. A. (I970). Autonomic hyperreflexia in urologic surgery. F.A.M.A. $213,867-869$.

Prys-Roberts, C., Lloyd, J. W., Fisher, A., Kerr, J. H. \& Patterson, T. J. S. (I974). Deliberate profound hypotension induced with halothane: studies of haemodynamics and pulmonary gas exchange. Brit. F. Anaesth. 46, I05-I I6.

Raventos, J. (I956). The action of Fluothane-a new volatile anaesthetic. Brit. $\mathcal{F}$. Pharmacol. II, 394-4IO.

Rosner, S., NewMan, W. \& Burstein, C. L. (I953). Electrocardiographic studies during endotracheal intubation, VI: effects during anaesthesia with thiopental sodium combined with a muscle relaxant. Anesthesiol. 14, 59I-595.

Stephenson, H. E., Jr. (I969). Cardiac Arrest and Resuscitation, 3rd edition. C. V. Mosby Company, St. Louis.

TAKeshima, K., NodA, K. \& Higaki, M. (I964). Cardiovascular response to rapid anaesthesia induction and endotracheal intubation. Anaesth. Analg. (Cleveland), 43, 20I-208.

Tomori, Z. \& Widdicombe, J. G. (1969). Muscular, bronchomotor and cardiovascular reflexes elicited by mechanical stimulation of the respiratory tract. $\mathcal{F}$. Physiol. (Lond.), 200, 24-49.

WeIsS, S. \& FERris, E. B. (I934). Adams-Stokes Syndrome with transient complete heart block of vagovagal reflex origin. Arch. Int. Med. 54, 93 I-95I.

WELPLY, N. (I975). Unpublished observations.

Winsor, T. \& Burch, G. W. (I946). Use of phlebomanometer. Amer. Heart F. 3I, 387-406. 